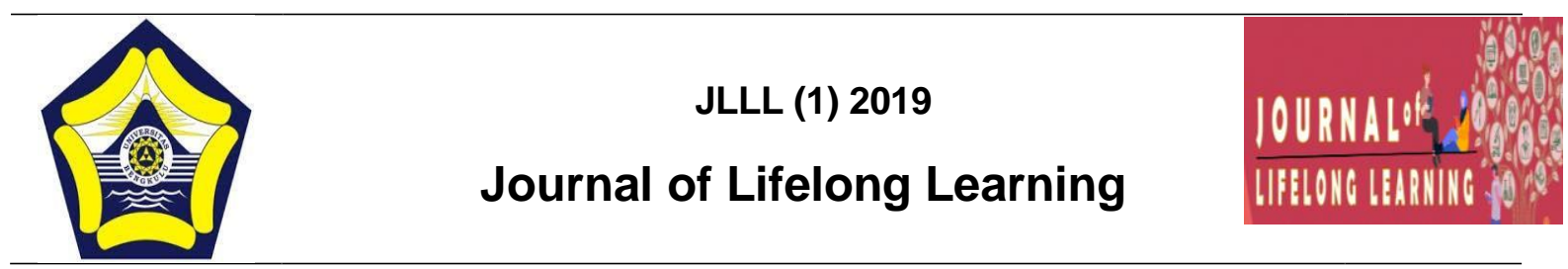

\title{
KEGIATAN BELAJARA MENGAJAR (KBM) DI LEMBAGA PENDIDIKAN KETERAMPILAN (LPK) CV. ARAU KOTA BENGKULU
}

\author{
Fera Utari ${ }^{1}$, Ilham ${ }^{2}$, Riskan ${ }^{3}$ \\ ${ }^{1}$ Nonformal Education, University of Bengkulu, Indonesia, feradianutari@gmail.com \\ ${ }^{2}$ Nonformal Education, University of Bengkulu, Indonesia, ilhamabdullah332@gmail.com \\ ${ }^{3}$ Nonformal Education, University of Bengkulu, Indonesia, alazharbengkulu5051@gmail.com
}

\begin{abstract}
This research in common to know how learning steers car on LPK CV. Arau is Bengkulu's City. Performing observationaling to utilize research by methodics case study, data collecting did by interview, observation and documentation. Base study result therefore gets to be concluded that 1) Management course steer car on institute course steer LPK CV'S car. Arau at Bengkulu's City was walking lam which is more or less 42 years but on penyelanggaraannya stills less professional as well as 2 instructor stipubting be accomplished appropriate persayaratan that affixed deep spontaneous number Minister Of Communication: 2 ) On institute course steers LPK CV. Arau doesn't establish 2 healthy bank statements and well-behaved from kepolisan becomes to stipulate becomes course participant which 2 it most loads in number Minister Of Communication decision: 3 ) Learning Material on institute course steer LPK CV.Arau's car there is and appropriate referenced curriculum steers. Meanwhile curriculum has accomplished partly criterion which at words by number Minister Of Communication decision: KM). 4 ) Learning Method utilize to methodic discourses, question-answer, training (drill) again and again, with blackboard media, traffic light banner and car fleets, theory pembelajarn not specific ala is utilized but at the moment researcher research sees instructor to utilize some pembelaran's theory principle as cognitive as s r, kognitif's theory and configurational motivation theory, steps in learning gets basis on learning curriculum steers car, 5 ) Learning Aim steer cars on LPK CV. 6 ) Evaluation those are done on learning steers car did by nontes's activity pattern where estimation was done by instructor utilize direct watch observation by instructor in assesses pengusaan tech steers can know don't it participant study to gain control tech implement studies
\end{abstract}

Key word: learning component on LPK CV. Arau is Bengkulu City 


\section{PENDAHULUAN}

Konsep pendidikan mengenal adanya tiga lingkungan pendidikan yaitu lingkungan pendidikan keluarga (informal), lingkungan pendidikan sekolah (formal), dan lingkungan pendidikan dalam masyarakat (nonformal). Undang-Undang Nomor 20 tahun 2003 tentang Sistem Pendidikan Nasional menggariskan bahwa satuan pendidikan adalah kelompok layanan pendidikan yang menyelenggarakan pendidikan pada jalur formal, nonformal, dan informal pada setiap jenjang dan jenis pendidikan. Yang mana ketiga lingkungan pendidikan tersebut saling melengkapi satu sama lainnya. Yang man lingkungan pendidikan formal berda pada lingkungan kelurga, selanjutnya lingkungan pendidikan formal pada jalur persekolahan, sdesngkan lingkungan pendidikan nonformal pada lingkungan pendidikan diluar jalur pendidikan formal seperti halnya lembaga kursus, PAUD, PKBM yang menjadi pelngkap penambah pengganti jalur peneidikan formal. Salah satu jenjang pendidikan nonformal yaitu lembaga kursus mengemudi mobil LPK CV. Arau kota Bengkulu yang mana lembaga ini telah berdiri kurang lebih 42 tahun dan merupakan lembaga kursus tertua dibidangnya di kota Bengkulu.

Semakin pesat perubahan dan perkembangan teknologi semakin pesat pula persaingan antar lembaga kursus, hal tersebut menarik peneliti untuk mengatahui mengapa lembag CV Arau masih tetap exsis di kota bengkulu walaupun sudah sekian lama dibuka pembelajaran seperti apa yang lembaga ini tawarkan dan berikan kepada peserta kursusnya. Hal tersebutlah yang melatar belakangi penelitian ini. Dari latar belakang tersebut kemudian peneliti membuat beberapa rumusan masalah yaitu 1) Bagaimana kompetensi instruktur mengemudi mobil, 2) Bagaimana kemampuan warga belajar mengemudi mobil, 3) Bagaimana materi pembelajaran kursus mengemudi mobil, 4) Bagaimanakah metode, media, teori pembelajaran dan langkah-langkah tahapan dalam pelaksanaan dalam proses pembelajaran mengemudi mobil, 5) Apa tujuan pembelajaran mengemudi mobil, 6) Bagaimanakah evaluasi pembelajaran kursus mengemudi mobil di LPK CV. Arau Kota Bengkulu.

\section{METODE}

Peneliti menggunkan metode kualitatif dengan pendekatan studi kasus. Menurut Iskandar dalam Seftyani ( $2013: 22$ ) studi kasus adalah penelitian tentang suatu kasus dengan telaah lebih mendalam dan kesimpulannya tidak untuk generalisasi atau kesimpulan hasil penelitian tidak dapat berlaku atau terbatas untuk kasus lainnya. subjek yang dipilih adalah Ibu Eli Marni sebagai pengelola, bapak T.M.Mangkubumi BAC sebagai Divisi Pendidikan, bapak Hartomo dan M. Deby Antony sebagai instruktur kursus mengemudi mobil serta Evan Saputra S.T sebagai salah satu wakil dari warga belajar lembaga kursus mengemudi mobil di CV Arau Kota Bengkulu. Lokasi dalam penelitian ini adalah Pada Lembaga Pendidikan Keterampilan CV Arau, yang beralamatkan di Jln. Puteri Gading Cempaka. No.30, Kota Bengkulu. Teknik pengumpulan data menggunakan observasi, wawancara dan dokumentasi Selanjutnya untuk teknik validitas data menggunakan reduksi data, penyajian data dan penarikan kesimpulan. Dan untuk keabsahan data pada penelitian ini menggunakan triangulasi subjek, tiangulasi waktu, dan triangulasi teknik. 


\section{HASIL DAN PEMBAHASAN}

1) Penyelenggaraan kursus mengemudi mobil pada lembaga kursus mengemudi mobil LPK CV. Arau di Kota Bengkulu telah berjalan lama yaitu kurang lebih 42 tahun tetapi pada penyelanggaraannya masih kurang profesional seperti halnya 2 persyaratan instruktur belum terpenuhi sesuai persayaratan yang tercantum dalam Keputusan Menteri Perhubungan nomor : KM.36 tahun 1994 bab V tentang persayaratan instruktur pasal 15 yaitu Surat Keterangan Berkelakuan Baik Dari Kepolisian Daerah dan tidak ada sertifikat kursus khusus untuk instruktur. Dan satu kompetensi instruktur yaitu kompetensi pedagogik yang tercantum di dalam permendikbud nomor 41 tahun 2009 tentang Standar Pembimbing Pada Kursus dan Pelatihan,

Instruktur tidak membuat silabus serta RPP hanya beracuan pada kurikulum lembaga kursus mengmudi mobil LPK CV. Arau. Dan satu kompetensi instruktur yaitu kompetensi pedagogik yang tercantum di dalam permendikbud nomor 41 tahun 2009 tentang Standar Pembimbing Pada Kursus dan Pelatihan, instruktur tidak membuat silabus serta RPP hanya beracuan pada kurikulum lembaga kursus mengmudi mobil LPK CV. Arau. 2) Pada lembaga kursus mengemudi LPK CV. Arau tidak menetapkan 2 surat keterangan sehat dan berkelakuan baik dari kepolisan menjadi syarat menjadi peserta kursus yang mana 2 hal ini termuat di dalam Keputusan Menteri Perhubungan nomor: KM.36 Tahun 1994 tentang Pendidikan Mengemudi Bermotor Pasal 14 yang mana hal ini dapat menjadi masukan bagi lembaga agar meningkatkan kualitas lembaga melalui disiplin pada syarat menjadi warga belajar kebaikan kelancaran dalam pembelajaran. Cara digunakan oleh instruktur untuk mengetahui batas kemampuan peserta didik yaitu melakukan pendekatan personal untuk bisa menyesuaikan dan memberi pembelajaran menyesuaikan kemampuan peserta kursus (inteligensi). 3) Materi pembelajaran pada lembaga kursus mengemudi mobil LPK CV.Arau ada serta sesuai acuan kurikulum mengemudi. Sedangkan kurikulum telah memenuhi sebagian kriteria yang di jelaskan oleh Keputusan Menteri Perhubungan nomor : KM.36 tahun 1994 bab III tentang Kurikulum pasal 12 yakni : Kurikulum penyelenggaraan pendidikan mengemudi kendaraan bermotor roda 4 jenis mobil manual pada lembaga kursus mengemudi mobil LPK CV. Arau Kota Bengkulu telah mencakup teori dan praktek.

Sesuai observasi peneliti pada buku panduan pembelajaran mengemudi mobil, materi pembelajaran pada lembaga kursus mengemudi mobil LPK CV. Arau Kota Bengkulu telah memenuhi kriteria materi pembelajaran yang baik menurut Ayiolim (2011:107). 4) Metode pembelajaran menggunakan metode ceramah, metode tanya jawab, metode latihan (drill) secara berulang-ulang dan Metode Simulasi. Media digunakan oleh instruktur yaitu media visul seperti spanduk rambu-rambu lalu lintas ditempel pada dinding ruang pembelajaran teori, dan kantor lembaga, media papan tulis, dan menggunakan buku panduan mengemudi mobil dan jika latihan mengemudi mobil media yang digunakan mobil langkah-langkah dalam pembelajaran instruktur memulai pembelajaran sesuai kemampuan peserta belajar dan memberikan pembelajaran sesuai kurikulum dan buku panduan. 
Teori pembelajaran yang digunakan oleh instruktur tidak menggunakan teori khusus hanya saja saat penelitian temuan peneliti bahwa instruktur menggunakan beberapa prinsip-prinsip yang terdapat pada ke tiga teori pembelajaran seperti teori S-R, teori Kognitif, teori Motivasi dan kepribadian.5) Tujuan pembelajaran mengemudi mobil pada LPK CV.Arau Kota Bengkulu yaitu untuk membentuk SDM peserta belajar yang memiliki skill keahlian dalam mengemudi mobil yang mana mencakup semua keahlian yang termuat dalam kurikulum pembelajaran mengemudi mobil lembaga CV.Arau, 6) Evaluasi yang dilakukan pada pembelajaran mengemudi mobil dilakukan dengan pola kegiatan nontes dimana penilaian dilakukan instruktur menggunakan observasi pengamatan langsung oleh instruktur dalam menilai pengusaan teknik mengemudi bisa tau tidaknya peserta belajar menguasai penerapan teknik belajar. Sesuai wawancara kepada pengelola bahwa evaluasi pembelajaran warga belajar dengan predikat sertifikat A mencapai $80 \%$, sedangkan $20 \%$ lagi dengan predikat B dan C dalam waktu setahun belakang.

\section{PENUTUP \\ KESIMPULAN}

Pada hasil penilitaian yang peneili lakukan pada lapangan maka dapat disimpulkan bahwa pada pelaksanaannya lembaga pendidikan keterampilan LPK CV. Arau Kota Bengkulu telah brejalan baik tetapi hanya terdapat beberapa kekurangan dan ini dapat menjadi masukan bagi lembaga lebaga kursus untuk meningkatkan mutu dan keprofesionalitas kinerja lembaga. Berdasarkan pembahasan dan kesimpulan penelitian yang telah dikemukakan, maka penulis ingin menyampaikan beberapa saran untuk Pembelajaran Kursus Mengemudi Mobil pada LPK CV.Arau Kota Bengkulu kepada :

1. Pimpinan LPK CV.Arau

1) Untuk membuat profil dan struktur kepengurusan yang terbaru

2) Untuk mengajukan kembalai permohonan Akreditasi Ke BAN PAUD dan PNF Bengkulu

3) Untuk menambah persayaratan menjadi instruktur dan warga belajar yaitu Surat Keterangan Berkelakuan Baik Dari Kepolisian Daerah serta memiliki sertifikat Telah mengikuti kursus instruktur mengemudi kendaraan bermotor selama 150 jam pelajaran yang diselenggarakan oleh POLRI atau instansi yang bertanggung jawab dibidang lalu lintas dan angkutan jalan,

4) Memberikan tugas instruktur untuk membuat silabus serta RPP

5) Menambah persayaratan menjadi warga belajar yaitu Sehat jasmani dan rohani yang dibuktikan dengan surat keterangan dokter; Berkelakuan baik dengan dibuktikan dengan surat keterangan kepolisian setempat tidak menjadi syarat menjadi warga belajar pada lembaga kursus mengmudi mobil LPK CV. Arau

6) Menambah standar kelulusan pada lembar evaluasi untuk menambah kualitas lulusan kursus mengemudi seperti yang dijelakskan SKL Lembaga Kursus Mengemudi Bermotor yang termuat di Direktorat Pembinaan Kursus dan Pelatihan Direktorat Jenderal Pendidikan Anak Usia Dini Nonformal dan Informal Kementerian Pendidikan dan Kebudayaan 2012 
7) Untuk Memperbaharui dan menambah kelengkapan materi pembelajaran pada modul pembelajaran seperti pada awal menjelaskan semua bagian-bagian dan fungsinya serta cara menggunakannya selanjutnya bisa dipaparkan mengenai pemeriksaan sebelum mengemudi mobil apa saja, baru ke semua teknik mengemudi, selanjutnya bisa dibahas penyetelan spion dan lampu,setelah itu bisa di bahas mengenai indikator yang perlu diperhatikan seperti pengisisn ACCU, suhu mesin, bahan bakar, tekanan oli, rem tangan, pinti/bagasi, selanjutnya bisa di bahas mengani keterampilan-keterampilan penting bagi pengemudi

8) Merekrut tenaga instruktur mengemudi mobil wanita, sehingga peserta belajar wanita lebih leluasa dan lebih nyaman jika sama-sama wanita belajar mengemudi

\section{REFERNSI}

Abdul Kadir Munsyi Dip. Ad. Ed, tanpa tahun. Tersedia di https://totoyulianto.wordpress.com/2013/03/02/metode-pemberian-tugas-resitasi-penerapani-metode-pembelajaran/. Di akses pada tanggal 14 Juni 2017

Ainamulyana(2015). Tersedia di http://ainamulyana.blogspot.com/2015/04/metode-tanya-jawabdan-prinsip.html. di Akses pada tanggal 14 juni 2017

Anitah, Sri, W, dkk. (2007). Strategi Pembelajaran di SD. Jakarta: Universitas Terbuka.

Apriani Wiwin (2013:48).Perencanaan Pusat Pelatihan mengemudi di Kota Pontianak.(Jurnal Online)

Arsyad Azhar(2014) tersedia di http://ainamulyana.blogspot.com/2012/01/pengertian-metodepembelaaran-dan.html)

Ayoilim (2013:107) tersedia di https://ayiolim.wordpress.com/2011/02/23/manajemen-pelatihan/

Buntarto,2014.Teknik Mengemudi Mobil Hemat Bahan Bakar.Yogyakarta.PUSTAKABARUPRESS

Ciri-ciri instruktur yang baik tersedia di http://binalpksabang.blogspot.co.id/2014/10/tenagapelatih-instruktur-pelatihan.html?m=1. Di akses pada 23 Oktober 2016

Dalam GBHN tahun 1973, GBHN 1978, GBHN 1983 dan GBHN 1988 Bab IV bagian pendidikan berbunyi: Pendidikan Nasional berdasarkan Pancasila.

Dalam buku Dr Abraham H.Maslow yang berjudul "Motivation and Personality" tersedia di http://arikathemousleemah.blogspot.co.id/2014/09/makalah-msdm-motivasi-menurutteori.html?m=1, 30 november 2016

Depdikbud.Kamus Besar Bahasa Indonesia,Jakarta:Balai Pustaka,1996 Pengertian Kursus,Jakarta:Balai Pustaka,1996 Pengertian Pembelajaran ,Jakarta:Balai Pustaka,1996 Pengertian Metode ,Jakarta:Balai Pustaka,1996

Depdiknas. 2003. Undang-Undang Republik Indonesia Nomor 20 Tahun 2003, tentang Sistem Pendidikan Nasional..jakarta: Cipta jaya. 
Sisdiknas Pasal 1 Ayat 20.Jakarta:Cipta Jaya

Sisdiknas Pasal 26 ayat 3.Jakarta:Cipta Jaya

Dirman dan Cicih Juarsih,2014,Jakarta:Teori Belajar dan Prinsip-Prinsip Belajar $\quad$ yang Mendidik.PT RINEKA CIPTA.

Penjelasan Teori Kognitif di dalam Dirman dan Cicih Juarsih,2014,Jakarta:Teori Belajar dan Prinsip-Prinsip Belajar yang Mendidik.PT RINEKA CIPTA.

Djamarah, Syaiful Bahri \& Aswan Zain. 2010. Strategi Belajar Mengajar. Jakarta: Rineka Cipta.

Djamarah (2002). Tersedia di http://zonainfosemua.blogspot.co.id/2015/02/pengertian-modelpembelajaran-karya.html. di akses pada tanggal 14 Juni 2017

Djarto.2008.Pendidikan Keaksaraan. http://pendidikankeaksaraan.blogspot.co.id/.Diakses pada 1 november 2016

fahruroji ,2013.termuat di https://www.scribd.com/doc/40610381. diakses pada 30/04/2017

Gage dan Berliner (1981:457). Tersedia di http://belajarpsikologi.com/macam-macam-metodepembelajaran/. Di akses pada tangggal 14 juni 2017

Hamalik, Oemar. 1994. Media Pendidikan. Bandung: Citra Aditya Bakti

Prinsip Pembelajaran Teori S-R,Teori Kognitif,Teori Motivasi dan Kepribadian di datam Moedzakir Djauzi.Pendidikan Luar SekolahRevitalisasi Konsep. Yogyakarta:Aditya Media

Haryanto (2013). Terdesia di http://belajarpsikologi.com/macam-macam-metode-pembelajaran/. Di akses pada tanggal 14 juni 2017

Idtesis (2007). Tersedia di https://idtesis.com/metode-pembelajaran-kerja-kelompok/. Di akses pada tanggal 14 Juni 2017

Indry,2012, tersedia di https://indrycanthiq84.wordpress.com/pendidikan/komponen-komponenpembelajaran-konsep-dasar-peserta-didik-pendidik-tujuan-dan-bahanmateril. Diakses pada tanggal 13maret 2017

Joko Subagyo, P. 2006. Metode Penelitian Dalam Teori Dan Praktek. Rineka Cipta. Jakarta.

Keputusan Menteri Perhubungan nomor : KM.36 Tahun 1994, tersedia di

https://www.google.co.id/url?sa=t\&rct=j\&q=\&esrc=s\&source=web\&cd=1\&cad=rja\&uact=8

\&ved=0ahUKEwib65iyhY3UAhVJOI8KHaAtCwAQFggjMAA\&url=http\%3A\%2F\%2Fhub

dat.dephub.go.id\%2Fkm\%2Ftahun-1994\%2F140-km-36-tahun-1994-ttg-pendidikan-

mengemudi-kendaraan-

bermotor\%2Fdownload\&usg=AFQjCNGW2VnhErn8SzZQiyE6clkmSRgf6w\&sig2=aLhhx 44xAAy_3-J0hVm_9A. Diakses pada tanggal 07 Mei 2017

Komponen pembelajaran tersedia di http://www.definisi-pengertian.com/2015/05/definisi-danpengertian-pembelajaran.html. diakses pada pukul 20:56

Mc Leish (1976). Tersedia di http://belajarpsikologi.com/macam-macam-metode-pembelajaran/. Di akses pada tanggal 14 Juni 2017 
Moedzakir, D,2013. Pendidikan Luar Sekolah Revitalisasi Konsep. Aditiya Media Pblishing.

Moleong,2005.Metodologi Kualitatif Edisi Revisi. Bandung: PT Remaja Rosdakarya

Moleong, J.Lexy,2002,Metode Penelitian Kualitatif.Bandun:RemajaKarya

Mudhofar Ali.2011.Ciri-Ciri Instruktur yang Baik. Tersedia di http://alimudhofar.blogspot.co.id/2011/04/ciri-ciri-instruktur-yang-maik.html. di akses pada 29 Desember 2016

Mulyasa.tersedia di http://zonainfosemua.blogspot.co.id/2015/02/pengertian-modelpembelajaran-karya.html. di akses pada tanggal 14 Juni 2017

Muthoharoh Hafiz (2010). Tersedia di https://alhafizh84.wordpress.com/2010/01/16/metodesosiodrama-dan-bermain-peranan-role-playing-method/. Di akses pada tanggal 14 juni 2017

Muhamad Syarif Efendi,2015,Strategi Pembelajaran Teori dan Praktik di Tingkat Pendidikan Dasar.Jakarta.PT RajaGrafindo Persada

Nana Sudjana dalam buku Dasar-dasar Proses Belajar Mengajar, (1989:78-86), tersedia di http://ainamulyana.blogspot.com/2012/01/pengertian-metode-pembelaaran-dan.html).

Nurhalim, Khomsum. 2014. Strategi Pembelajaran Pendidikan Nonformal.

Nurianti Erin. 2011. Konsep Dasar Kursus.tersedia di http:// erinnurianti.blogspot.co.id/2011/03/konsep-dasar-kursus.html?m=.di akses pada 29 Desember 2016

Pengertian kursus yang termuat dalam Direktur Jenderal Pendidikan Luar Sekolah, Pemuda, dan Olahraga (Kepdirjen Diklusepora) Nomor : KEP- 105/E/L/1990

Pengertian kursus tersedia di https://id.wikipedia.org/wiki/Kursus. di akses 23 Oktober 2016

Pengertian pendidikan life skill tersedia di http://www.definisi-pengertian.com/2015/05/definisipengertian-kecakapan-life-skill.html, diakses 1 november 2016

Pengertian pembelajaran https://www.seputarpengetahuan.com/2015/03/15-pengertianpembelajaran-menurut-para-ahli.html. diakses pada , 30 november 2016

Pengertian pendidikan keasksaraan tersedia di http://pendidikankeaksaraan.blogspot.co.id/. Diakses pada pukul 22:43 1 november 2016

Peran instruktur tersedia di http://binalpksabang.blogspot.co.id/2014/10/tenaga-pelatihinstruktur-pelatihan.html?m=1. Di akses pada 23 Oktober 2016

Peraturan Menteri Pendidikan dan Kebudayaan No. 41 Tahun 2009 Tentang Standar Pembimbing Pada Kursus dan Pelatihan

Peraturan Pemerintah No 19 Tahun 2005 Tentang

Standar Nasional Pendidikan. http://eprints.unlam.ac.id/75/1/5\%20Peranan\%20Lembaga\%20Kursus\%20dalam\%20Pembe rdayaan\%20Masyarakat\%20Balangan.pdf 
Peraturan Pemerintah No.73 Tahun 1991 tentang Tujuan Pendidikan Luar Sekolah (PLS)

Peraturan Pemerintah Tahun 1991 BAB 1 ayat 1 tentang pengertian Pendidikan Luar Sekolah

Peraturan pemerintah tahun 1993 tentang kendaraan dan pengemudi Pasal 2 ayat 1 tentang pengelompokan jenis kendaraan bermotor menjadi 5 jenis

Rheba de dan Martha A. Thompson, 1987. Termuat di http://mukayahaya.blogspot.co.id/2016/02/makalah-metode-simulasi.html

http://mukayahaya.blogspot.co.id/2016/02/makalah-metode-simulasi.html. di akses pada tanggal 14 juni 2017

Riyana Cepi,2009, pengertian tujuan pembelajaran tersedia di

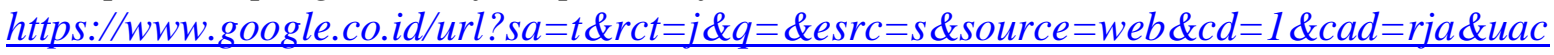
t=8\&ved=OahUKEwi8p7f339nSAhWFJpQKHYBKAfkQFggbMAA\&url=http\%3A\%2F\%2Ff ile.upi.edu\%2FDirektori\%2FFIP\%2FJUR._PEND._LUAR_BIASA\%2F196209061986011AHMAD_MULYADIPRANA\%2FPDF\%2FKomponen_Pembelajaran.pdf\&usg=AFQjCNH4 D5iYQj2zh5sVmc2JwBs8X-E5hg\&sig2=77NmttN2tn3YrQwVqfxa4Q. Di akses pada 8 januari 2017

Rizema Sitiatava,2013.Desain Evaluasi Belajar Berbasis Kinerja.Diva Press.Jogjakarta.

Roestiyah N.K, 1989. Tersedia dihttps://totoyulianto.wordpress.com/2013/03/02/metodepemberian-tugas-resitasi-penerapan-i-metode-pembelajaran/. Di akses pada tanggal 14 Juni 2017

Saepudin Usep. 2012. Pendidikan Anak Usia Dini.

http://usepsaepudin66.wordpress.com/kurikulum-pendidikan-agama-islam-dalampendidikan-luar-sekolah-pls/. Diakses pada 1 november 2016

Sanjaya Wina,2006, Strategi Pembelajaran Berorientasi Pada Standar Proses

Pendidikan.Kencana.Jakarta

Sagala, S. 2008. Konsep dan Makna Pembelajaran. Bandung: Alfabeta

Semarang: Unnes.

http://eprints.unlam.ac.id/75/1/5\%20Peranan\%20Lembaga\%20Kursus\%20dalam\%20Pembe rdayaan\%20Masyarakat\%20Balangan.pdf

Seftiyani, 2013. Studi Penyelenggaraan Koperasi Pendidikan Luar Sekolah. Skripsi Jurusan Pendidikan Luar Sekolah. Tidak Untuk di Terbitkan.

Sudjana.2004.Pendidikan NonFormal.(Wawasan, Sejarah, Perkembangan, Filsafat \& Teori Pendukung serta asas).Bandung:Falah Production

Sugiyono,2003,Metode Penelitian Administrasi.Bandung:Alfabeta

Sugiyono,2006,Metode Penelitian Kuantitatif dan Kualitatif.Bandung:Alfabeta

Sumantri, Mohamad syarif. 2015. Strategi Pembelajaran : Teori Dan Praktik Di Tingkat

Dasar. Jakarta: PT Raja Grafindo Persada

Sutarto. Joko. 2007. Pendidikan Non Formal (Konsep Dasar, Proses Pemberdayaan, dan

Pemberdayaan Masyarakat). Semarang : UNNES Press. 
Soetomo et al (1988: 2.17), tersedia di https://www.google.co.id/url?sa=t\&rct=j\&q=\&esrc=s\&source=web\&cd=1\&cad=rja\&uact=8 \&ved=0ahUKEwjVrPGXgo3UAhUJNI8KHYbtDmEQFggnMAA\&url=http\%3A\%2F\%2Fp ublikasi.data.kemdikbud.go.id\%2FuploadDir\%2Fisi_BAC8187B-9A40-4431-A7C22B21312A929C_.pdf\&usg=AFQjCNFSMWMrSdYeP1ZFHxdsDMVb6zCO3A\&sig2=viro UholYtGibyHJ8gbJTg. Diakses pada tanggal 02 Mei 2017

UU NO 22 Tahun 2002 Tentang Lalu Lintas dan Angkutan Jalan.tersedia di kompas.com http://otomotif.kompas.com/read/2015/09/29/150400515/Indonesia

UU No 20 Tahun 2003 Pasal 1 Point 4, http://publikasi.data.kemdikbud.go.id/uploadDir/isi_BAC8187B-9A40-4431-A7C22B21312A929C.pdf

UU Sistem Pendidikan Nasional pasal 26 ayat 5. Tersedia di https://www.google.co.id/url?sa=t\&rct=j\&q=\&esrc=s\&source=web\&cd=5\&cad=rja\&uact=8 \&ved=0ahUKEwiU4rbkovUAhULpY8KHXB8AlkQFgg_MAQ\&url=http\%3A\%2F\%2Fpendis.kemenag.go.id\%2F file\%2Fdokumen\%2Fuuno20th2003ttgsisdiknas.pdf\&usg=AFQjCNFXESzGphDHbQ6N9ai 8Q09s-YTNHw\&sig2=iZM_BZ-MGjFlWlwTc3VT5w

Peraturan Pemerintah Republik Indonesia Nomor 44 tahun 1993 tentang jenis dan konstruksi kendaraan bermotor paragraf 1 pasal 2, tersedia di https://www.google.co.id/url?sa=t\&rct=j\&q=\&esrc=s\&source=web\&cd=1\&cad=rja\&uact=8 \&ved=0ahUKEwiMtr3Sk4vUAhXKrI8KHcYwCYYQFggjMAA\&url=http\%3A\%2F\%2Fhu bdat.dephub.go.id\%2Fperaturan-pemerintah\%2F82-pp-no-44-tahun-1993-ttg-kendaraan$\underline{\text { dan- }}$

pengemudi\%2Fdownload\&usg=AFQjCNGVtphiVet19ckOgFwU11BBYPvNow\&sig2=vsau nsQ1_7Ph7Uzbm2CxGw. Di akses pada tanggal 7mei 2017

Yasin Sanjaya (2012). Tersedia di http://www.sarjanaku.com/2012/04/metode-drill-pengertianprinsip-tujuan.html. di akses pada 14 Juni 2017

Zulkarnaen Rufran.2013.Bahan Ajar Manajemen Kelembagaan dan Pembiayaan Pendidikan Luar Sekolah. 